\title{
Restriction Enzyme Cleavage Site
}

National Cancer Institute

\section{Source}

National Cancer Institute. Restriction Enzyme Cleavage Site. NCI Thesaurus. Code C54667.

The specific DNA base that is cut by a specific restriction enzyme. 